\title{
Human Rights Violations and the Policy Crossroads
}

If our floods go away, what will we do? We have nowhere to go - nowhere to take our. children. You will find our bones here.

[Dasanech agropastoral woman in the Omo River delta]

\begin{abstract}
The pursuit of Omo River basin development is leading to a major human rights crisis in the Ethiopia-Kenya-South Sudan transboundary region of eastern Africa. Among the principal human rights being violated are those recognized by the International Covenant on Economic, Social and Cultural Rights (ICESCR) Treaty adopted by the U.N. General Assembly. Although the Ethiopian government is most immediately responsible for initiating human rights violations in the region, the Kenyan government and international development banks are variously complicit, collaborative and partnered in these transgressions. The World Bank, African Development Bank and major donor countries continue to support — even legitimate - the development despite predictable destruction of hundreds of thousands of indigenous peoples' livelihoods and major political rights violations, particularly within Ethiopia. Cumulative and synergistic effects of the Gibe III megadam and its linked irrigated plantations and energy export transmission system must be integrally considered for adequate social and environmental impact assessment, yet both governments and development banks have failed to act on this mandate. A crossroads in public policy has now emerged: either pursue the present pathway toward massive scale hunger, regional economic collapse and major new cross-border armed conflict or suspend the development underway in order to take genuine account of human rights and proceed in a direction that is accountable to citizens and provides for a sustainable future for the three nations involved.
\end{abstract}

\section{The Crisis Unfolding and the Human Right to Context}

Previous chapters of this book have detailed how and why the Gibe III hydrodam-one of the world's tallest, together with its linked irrigated agricultural and electricity export transmission development-is creating a human rights as well as humanitarian crisis in the transboundary region of Ethiopia-Kenya-South Sudan (Fig. 1.1). The indigenous population in these semi-arid lands is already subject to some of the highest levels of malnutrition, epidemic level disease and armed conflict in Sub-Saharan Africa.

Hundreds of thousands of indigenous pastoralists and agropastoralists, of multiple ethnicities in the region (Fig. 1.3) have been so severely disenfranchised over decades that they have had no recourse but to move to lands along the Omo River or Lake Turkana (Fig. 4.6). There they depend on river or lake waters for varying combinations of livestock raising, flood recession agriculture, fishing and other livelihood activities, as well as for potable water for household use. Government census information and international aid documents grossly underestimate the size of the vulnerable population and the real threat that these developments pose to their continued existence. 
Radical reduction in Omo River flow volume and the river's inflow to Lake Turkana. brought about by the Gibe III dam and dam-enabled irrigated agricultural enterprises, spells disaster for these river and lake dependent livelihood activities and the peoples depending on them. The reasons for the massive scale vulnerability and the dynamics involved are detailed throughout the chapters of this book. The overall dismantlement of livelihood systems, including complex survival strategies that have for centuries been able to adapt to their changing circumstances, are now pushed beyond their capacity to adjust.

For much of the indigenous population, the loss of Lake Turkana and Omo River water resources amounts to a virtual death sentence.

Added to this impending destruction is the plausible threat of Gibe III dam failure from earthquake or seismically triggered landslide events, causing unprecedented human and environmental decimation downstream in the Omo basin and around Lake Turkana. The scientific basis for postulating a $20 \%$ chance of a 7 or 8 magnitude earthquake in the Gibe III dam region during the next 50 years is outlined in Chap. 3. The Ethiopian government, Kenyan government and development banks, in their environmental and social impact assessments for the Gibe III dam, have unambiguously failed to take account of the potentially catastrophic destruction that would result from dam collapse or overtopping due to a seismic event.

If the Gibe III dam and dam-enabled irrigated agricultural commercial farms become operational, major escalation of conflict among ethnic groups - each desperate for access to the region's disappearing resources - would inevitably occur (Fig. 5.3), with major spillover into the Ilemi Triangle and South Sudan that are already embroiled in major conflict. In turn, the Kenyan and Ethiopian governments would increase their militarization of the region (a process already underway), in order to fortify their respective territorial claims and protect the activities of foreign corporations contracted by them to exploit the region's agricultural and petroleum resources. This process is already taken to an extreme in the lower Omo basin within Ethiopia.

Major oil and gas deposits exist throughout much of the transboundary region. Oil exploration activities have been underway for years prior to Ethiopian and Kenyan government public announcement of "newly discovered reserves" (see Appendix). Contrary to Tullow Oil and government statements, these activities have been undertaken without account of their impact on the region's hundreds of thousands of indigenous residents and their environment. As in other areas of East Africa and the Horn region, their actions have ignored international (U.N.) and national government mandates for "free and informed consent" by affected communities. Active exploration by the oil industry and related international aid funded infrastructural development within the region, have provoked local resistance — even militant — despite 'assurances' by industry and government representatives of 'major benefits' that will accrue to local communities. Numerous small legitimation efforts by the industry have been introduced in central and northern Turkana, including construction of small communal health small clinics and other facilities, school payments for Turkana children (e.g., by Tullow Oil), and small traveling theater groups dramatizing the positive outcomes of oil and gas development in Turkana lands. ${ }^{1}$

Transgressions of internationally recognized human rights by the Ethiopian and Kenyan governments, in collaboration with the AFDB and World Bank, center around violations of internationally recognized rights - to an adequate standard of living, to food and the means of producing it, to water and to freedom of political expression.

$>$ The United Nations drafted the International Covenant on Economic, Social and Cultural Rights (ICESCR) in the 1950s, in accordance with the Universal Declaration of Human Rights (UDHR) - passed in 1948 by the General Assembly. The ICESCR, also referred to as 'the Covenant', was passed by the U.N. General Assembly in December of 1966 and brought into force in $1976 .^{2}$

\footnotetext{
${ }^{1}$ These community 'contributions' are widely considered by Turkana elders to be 'bribes' for complicity with oil operations in their region.

${ }^{2}$ A succinct history of the U.N.'s human rights related multilateral treaties and treaty bodies is available (U.N. Office of the High Commissioner for Human Rights (OHCHR 2012).
} 
The ICESCR (Covenant) constitutes a multilateral treaty committing State parties to work toward the granting of economic, social and cultural rights to individuals. It formally recognizes the human right to an adequate standard of living, including the right to food, freedom from hunger and health, among other rights. The Covenant also specifies the steps to be undertaken by all State parties in order to realize those rights.

The Covenant has 164 State parties and is legally binding of all States signing and ratifying it. (The United States, along with Myanmar, for example, has signed but not ratified the treaty.) Both Kenya and Ethiopia have signed and ratified the ICESCRin 1972 and 1993, respectively. Those Articles of the Covenant most pertinent to the human rights noted above include the following.

-Article 1(2): In no case may a people be deprived of its own means of subsistence.

-Article 2(1): "Each State Party to the present Covenant undertakes to take steps, individually and through international assistance and co-operation, especially economic and technical, to the maximum of its available resources, with a view to achieving progressively the full realization of the rights recognized in the present Covenant by all appropriate means, including particularly the adoption of legislative measures." [Emphasis added. Note: "achieving progressively the full realization of the rights..." clearly implies no backsliding, or regressing.].

-Article 11(1): "The State parties to the present Covenant recognize the right of everyone to an adequate standard of living for himself and his family, including adequate food, clothing and housing, and to the continuous improvement of living conditions. [Emphases added].

-Article 12 (1, 2): "The States Parties to the present Covenant recognize the right of everyone to the enjoyment of the highest attainable standard of physical and mental health." and The steps to be taken by the States Parties to the present Covenant to achieve the full realization of this right shall include those necessary for..."The prevention, treatment and control of epidemic, endemic, occupational and other diseases."

$>$ The Committee on Economic, Social and Cultural Rights (CESCR) was established in 1985 to interpret specific Articles of the Covenant and to monitor its implementation by States parties. Established by U.N. Economic and Social Council (ECOSOC) Resolution 1985/17, the CESCR has 18 independent experts assigned these tasks. All State parties are required to present regular reports to the CESCR regarding their compliance with the rights established by the Covenant, whereupon the Committee carries out a multistage process of evaluation and subsequent dialogue with member States. Critics note the lack of effective U.N. oversight, largely due to insufficient funding and vulnerability to political pressures.

A series of General Comments are issued by the CESCR, two of which have critical implications in a consideration of human rights violations in the transboundary region.

- The Right to Food: CESCR General Comment 12. The CESCR's General Comment 12, issued in 1999, was largely in response to member States' requests following the 1996 World Food Conference for clarification of Article 11 of the Covenant concerning food. Follow-through meetings at the OHCHR and the FAO regarding the human right to food also contributed to the need for clarification. Most notable in the General Comment (GC 12) is the statement affirming the normative content of the Covenant's Article 11, paragraphs 1 and 2.

- "The right to adequate food is realized when every man, woman and child, alone or in community with others, have physical and economic access at all times to adequate food or means for its procurement" [Emphasis added.]

Further interpreting Article 11 of the Covenant, General Comment 12 (GC 12) states,

- "The right to adequate food, like any other human right, imposes three types or levels of obligations on States parties: the obligations to respect, to protect and to fulfil... The obligation to respect existing access to adequate food requires States parties not to take any measures that result in preventing such access. The obligation to protect requires measures by the State to ensure that enterprises or individuals do not deprive individuals of their access to adequate food. The obligation to fulfil means the State must proactively engage in activities intended to strengthen people's access to and utilization of resources and means to ensure their livelihood, including food security." (Section 15; Emphases added.] 
- More than two years prior to the GOE and development bank impact assessments, the U.N. High Commissioner for Human Rights (OHCHR) conducted a 2007 study of the specific obligations of States relative to access to safe drinking water and sanitation, with the conclusion that full recognition of such access should be recognized as a human right.

The OHCHR, in its Fact Sheet 35, has stated the following with regard to the human right to water as it pertains to both agriculture and pastoralism.- "Water is essential for life, but is also key to food security, income generation and environmental protection."

- General Comment No. 15 states that priority should be given to "the water resources required to prevent starvation and disease, as well as the water required to meet the core obligations of each of the Covenant rights." Bearing in mind the interdependence and indivisibility of all human rights, it can be said that the right to water ensures priority for water use in agriculture and pastoralism when necessary to prevent starvation. [Emphasis added].

- The Right to Water: CESCR General Comment 15. In November of 2002, the CESCR affirmed the right to water in Articles 11 and 12 of the Covenant and stated that this right is "inextricably linked" to other rights specified in the ICESCR - namely, the right to adequate food and health (CESCR 2002). ${ }^{3}$ By the General Comment 15, the CESCR considers that this is not limited to domestic uses but rather, extends to multiple uses of water-including for production. The CESCR did recognize, therefore, that water is required for other purposes including food production and other aspects of livelihood, even though it prioritized the right to water for personal and 'domestic' uses (ibid.).

- "The human right to water is indispensable for leading a life in human dignity. It is a prerequisite for the realization of other human rights." (Sect. 1; Emphasis added.)

— "The right to water is defined as the right of everyone to sufficient, safe, acceptable, physically accessible and affordable water for personal and domestic uses". (Sect. 2)

Article I.1 of the CESCR's General Comment No. 15 continues with these statements.

"Parties should ensure that there is adequate access to water for subsistence farming and for securing the livelihoods of indigenous peoples" (pg. 4)

"The Covenant specifies a number of rights emanating from, and indispensable for, the realization of the right to an adequate standard of living "including adequate food, clothing and housing." The use of the word "including," indicates that this catalogue of rights was not intended to be exhaustive. The right to water clearly falls within the category of guarantees essential for securing an adequate standard of living, particularly since it is one of the most fundamental conditions for survival."

The General Comment describes States' obligations to realize the human right to water:

"States must, at a minimum, show that they are making every possible effort, within available resources, to better protect and promote this right. Available resources refer to those existing within a State, as well as those available from the international community through international cooperation and assistance, as outlined in Articles 2 (1), 11 and 23 of the Covenant."

Among the other pertinent statements of Comment No. 15 are those "that individuals should be given equal and full access to information concerning water and the environment," (Para. 48).

- General Assembly Resolution 64/292: The Right to Water. The United Nations took a major step in advancing the formal acknowledgment of human rights in July/August of 2010, when the General Assembly (GA) adopted Resolution 64/292. The Resolution explicitly recognizes the right to water for drinking and sanitation and was adopted within the context of the Covenant's Article 11 (and the UDHR's Article 25.) For the first time, the U.N. formally recognizes:

- "The right to safe and clean drinking water and sanitation as a human right that is essential for the full enjoyment of life and all human rights."

\footnotetext{
${ }^{3}$ Comment No. 15 was published soon after, as E/C.12/2002/11 on January 20, 2003.

${ }^{4}$ General Assembly Resolution 64/292 (para. 1). The Human Right to Water and Sanitation, August 3, 2010.
} 
It also calls on States and international organizations to provide financial resources in order to provide safe, clean, accessible and affordable drinking water and sanitation for all.

Even a relatively strict interpretation of the relationship between the right to food and right to water-for example, one considering water as an input to food production-acknowledges that, "just like food and housing, an adequate supply of water is absolutely essential for an adequate standard of living, as it is necessary for the sustenance of life itself and for ensuring a life with dignity" (Winkler 2012) ${ }^{5}$. As such, it has the same status as the rights to food and housing that are also encompassed under the heading of the 'right to an adequate standard of living.'

It should be further noted that if drinking water, sanitation water and water for food production all come from the same sources in a given community, then protecting drinking water effectively means protecting all water. This is precisely the case in the lowermost Omo River basin and at Lake Turkana, where communities must utilize the same water for drinking and sanitation as for their major livelihood activities. Any application of General Assembly Resolution 64/292 by the Ethiopian and Kenyan States thus requires them to protect water sources used for all their needs.

- The U.N. Human Rights Council responded to the General Assembly's adoption of Resolution 64/292 with its own Resolution 15/9 on September 30, 2010, which:

-affirms that the rights to water and sanitation are part of existing international law, and

— confirms that these rights are legally binding upon States.

The Resolution also calls upon States to develop appropriate tools and mechanisms to 'progressively' achieve the full realization of such human rights obligations (in other words, without 'backsliding').

A number of closely related U.N. based declarations, conventions, international treaties and policy instruments have identified human rights violations in ways applicable to the transboundary region. One of these is the 2007 U.N. Declaration on the Rights of Indigenous Peoples (UNDRIP), adopted by the General Assembly in September 2007 (U.N., General Assembly 2007) — just as construction of Ethiopia's Gibe III dam was beginning. An outgrowth of the ILO Convention No. 169, UNDRIP issues the core assertion that indigenous peoples have rights to self-determination, lands, territories, natural resources and "free, prior and informed consent" (FPIC). Like the U.N. Declaration of Human Rights, UNDRIP is non-binding for states, but it provides a critical measure for interpreting human rights violations as they impact indigenous peoples.

- The African Charter on Human and Peoples' Rights was adopted by the Organisation of African Unity in 198118 years after the OAU was formed and came into force in 1986, in order to both "promote and protect" human and peoples' rights. As an instrument of human rights, the African Charter was comparable to such bodies in Europe. In accordance with Article 30 of the Charter, the African Commission on Human and Peoples' Rights (ACHPR) was set up in 1987, with the tasks of promoting and protecting human and peoples' rights and interpreting the Articles of the Charter. Responsibility of protecting rights to hear and rule on complaints as well as considering individual complaints of violations of the Charter. Meeting twice a year, the Commission has 11 members who are nominated by their own states (State parties) and elected by the AU Assembly. Presently, two of the eleven members are from Ethiopia and Kenya. ${ }^{6}$

Although the ICESCR is a multilateral treaty that is binding on all members since it came into force, a mechanism for individuals to bring a complaint against a member state when they have experienced violation of the Covenant was only established in 2008, with the U.S. General Assembly's adoption of the Optional Protocol to the ICESCR. As of 2013, enough states (although few African states) had ratified the Optional Protocol so that it did go into force. A Working Group on Economic, Social and Cultural Rights within the ACHPR is actively cooperating with an international network to promote ratification by African members states.

- A major complaint has been brought against the Ethiopian government by the Survival International Charitable Trust (SICT), citing the GOE's violation of at least four Articles of the African Charter-Articles recognizing the right to

\footnotetext{
${ }^{5}$ Broader interpretations of GA 64/292 consider the Resolution to go directly together with the rights to food. Both interpretations consider it to address an 'adequate standard of living.' See, for example, R.P. Hall et. al. (2013).

${ }^{6}$ The present Ethiopian ACHPR Commissioner is Chairperson of the ACHPR's Working Group on Extractive Industries, Environment and Human Rights Violations.
} 
Self-Determination, to Natural Resources, to Development and to Environment. SICT has brought these charges to the ACHPR on behalf of multiple indigenous peoples in the South $\mathrm{Omo}^{7}$. At the time of this book's submission for printing in 2015, the case is pending with the ACHPR.

- An important milestone in ACHPR recognition of ICESCR's recognition of the human rights to food, livelihood (standard of living) and water transpired in February of 2015, when the ACHPR adopted Resolution 300 on the Right to Water Obligations. In specifying the obligations of African States in implementing the right to water, the Commission has taken a rather broad view. The Resolution was in part the product of cooperation between the Commission and a group of civil society organizations (CSOs). ${ }^{8}$ Resolution 300 explicitly refers to the Commission's guidelines on Economic, Social and Cultural Rights (adopted in Tunis in 2011) which require States:

- "to protect water resources from pollution, to prioritize the provision of water for personal and domestic use and to protect the right to water and other related rights, the realization of which directly depends on water resources management." [Emphasis added.]

— "to strengthen natural resources governance...using a human rights approach...with the participation and in the interest of the population."

- [Observe] "Resolution 64/292 of the United Nations General Assembly and Resolution 15/9 of the United Nations

Human Rights Council."

The ACHPR expresses concern over "the negative effects of overuse...and other development activities threatening the rights of present and future generations, the realization of which depends on access to water," and urges African states to "protect the quality of national and international water resources and the entire riverine ecosystem." [Emphases added]. It remains to be seen how the Commission will apply Resolution 300.

\section{The Ethiopian Government's Violations of Human Rights in the Transboundary Region}

The Ethiopian government (GOE) has blatantly ignored ICESCR recognized human rights in its single-minded pursuit of the Gibe III and linked Omo River basin developments, despite predictable massive scale livelihood and human destruction throughout the transboundary region.

GOE violations of ICESCR recognized rights stem from several major dimensions of its actions:

(i) The planning, design and construction of the Gibe III dam, dam-dependent irrigated agricultural commercial farms (and infrastructure for it), and an electricity export system (EHPP) - all without regard for the survival needs of affected indigenous peoples in Ethiopia and Kenya.

(ii) The radical reduction of Omo River flow volume and inflow to Lake Turkana, causing widespread desiccation of the lowermost riverine zone in the lower Omo basin and major lake retreat - in turn, destroying pastoral, agropastoral and fishing livelihoods of hundreds of thousands of residents (see Figs. 5.2, 7.14 and 9.10).

(iii) The forceful, even brutal expropriation of indigenous lands and eviction of communities from their village areas along the Omo River - with ongoing denial of their right to political expression or dissent.

The Ethiopian government's actions in the lowermost Omo basin have consistently violated Articles of the Constitution of Ethiopia (for example, Article 40), its own environmental laws, and government agency as well as ministry operational requirements. Even a partial list of Ethiopian standards being violated must include:

- The Environmental Policy of Ethiopia (EPE) addressing environmental and social accounting.

- The National Conservation Strategy.

\footnotetext{
${ }^{7}$ The complaint filed by SICT does not explicitly address the borderlands between Ethiopia and Kenya, however, nor the hundreds of thousands of indigenous peoples residing around Kenya's Lake Turkana.

${ }^{8}$ The CSOs include the Platform for International Water Law (University of Geneva), WaterAid, the Legal Resources Centre, WaterLex and Green Cross.
} 
— Required procedures of the Environmental Protection Authority (EPA) - since 2013, renamed the Ministry of Environmental Protection and Forestry. ${ }^{9}$

- Proclamations including No. 299/2000 requiring environmental impact assessments to address sustainable development and 'EIAs' to be conducted for policies, programs and plans, as well as development projects. ${ }^{10}$

The Ethiopian government's violations of even its own mandated actions include its failures to:

- Conduct a downstream environmental/socioeconomic impact assessment (ESIA) for the Gibe III dam until more than two years after construction began - even then, producing only a geogaphically fragmentary assessment rather than addressing the actual impact area (the transboundary zone) with major omissions, misrepresentations and falsifications (see Chap. 6 for a detailed enumeration and discussion of Ethiopia's ESIAs).

- Consider the cumulative and synergistic effects of the linked developments in the Omo basin - the Gibe III dam, its linked irrigated agricultural enterprises and electricity export transmission system.

- Observe indigenous land and resource use rights, including those in Ethiopian land administrative law pertaining to pastoralists. Instead, state sponsored/approved forcible encroachment by private interests into communal lands predominates.

- Genuinely inform and consult populations prior to the inception of development—rather than 'manufacture' 'consent' from orchestrated and government (or donor) controlled gatherings.

- Implement a valid assessment of the efficacy of 'compensation' or 'mitigation' for the hundreds of thousands of indigenous residents, even if such were a genuine GOE intention.

- Implement its own defined Environmental and Social Management Framework (ESMF)—after such is shaped with community consultations. ${ }^{11}$

Repeated assertions by the Ethiopian government, particularly EEPCO, that the 'benefits' of Gibe III generated electricity would serve the needs of Ethiopians so far without access to power contradicted by two realities. Firstly, a high proportion of Gibe III generated electricity is slated for export, as outlined in prior chapters and in the section below. Secondly, since electricity costs in Ethiopia are predicted to rise by a minimum of $200 \%$ in the near term, according to the World Bank, the overwhelming proportion of Ethiopian citizens would have no means to purchase available electricity. This is true even with the unlikely scenario that the GOE subsidizes energy costs for large numbers of the poor. The major consumers of electricity - in Ethiopia, Kenya and elsewhere in eastern Africa — are projected to be industry, agroindustry, commerce and government entities, along with relatively better well-off domestic consumers.

$>$ Systematic actions taken by Ethiopia's institutional nexus of river basin development policy (see description in Chap. 2) over more than five decades for more than five decades reveal a clear pattern of ignoring the human and environmental consequences of major hydrodam development - the Gibe III being the worst case, to date. The close coordination and overlapping objectives among GOE Executive offices, international development banks (playing the key role among aid agencies in large capital projects) and global consulting industry members — both firms and individuals - form the functional core of bringing about such massive dam and infrastructural projects as the Gibe megadam.

The GOE's dismissive approach to the survival and well being of its own indigenous population within the lower Omo basin residents is evident from these two statements by Meles Zenawi, the late Prime Minister of Ethiopia, at Ethiopia's Annual Pastoralists' Day in 2011.

-On this occasion, I assure the people of South Omo, especially the pastoralists, that the time of losing your cattle or life because of the Omo flood is over. In the coming five years, there will be a very big irrigation project and related agricultural development in this zone. I promise you that, even though this area is known as backward in terms of civilization, it will become an example of rapid development. I also want to assure you that the work we have started

\footnotetext{
${ }^{9}$ The former head of the EPA became an advisor to the new Environmental Protection and Forestry Ministry.

${ }^{10}$ See Sect. 4.1 .3 of Proclamation No. 299/2000, for example.

${ }^{11}$ The Environmental and Social Management Framework, established in 2007 with World Bank funding of about USD 100 million, requires integrated consideration of social and environmental aspects and outcomes, including with account of cumulative, additive and synergistic effects of projects in development. The planning procedures actually enforced by the GOE were antithetical to such integral consideration.
} 
in this area on infrastructure and social development will continue stronger than ever. I want to assure you again that all our development work will be in line with protecting the environment and the friends of backwardness and poverty, whatever they say or do, can't stop us from the path of development we are taking. [Emphasis added.] ${ }^{12}$

-These people [dam critics] are concerned that butterflies will be disturbed by such projects and they will not allow the disturbance of butterflies even if this means millions of people have to be subjected to the deadliest killer diseases of all, poverty, in order to not disturb the butterflies.

Ethiopia's top officials frequently issue comparable statements regarding both the "backwardness" of the indigenous peoples in the Omo region and the 'colonial' perspectives or 'ignorance' on the part of organizations and individuals who have strongly objected to Gibe III dam and agricultural enterprises and the GOE's repressive policies in the Omo basin (see for example, the EEPCO website, http://www.gibe3.com/et).

GOE violations of ICESCR and African Charter recognized human rights in the lower Omo basin should be viewed within the broader Ethiopian context. GOE rights violations are abundantly documented in news accounts and at the websites of numerous Ethiopian diaspora groups and individuals. These violations detail the detention and imprisonment of political dissidents including journalists, scholars, artists and community activists; summary eviction of rural peoples for the privatization of their lands, and use of brutality in countering political resistance to these and other GOE actions-especially in minority pastoral and agropastoral areas. The western Ethiopia Gambella area is one of the most widely publicized areas of such actions within western and southwestern Ethiopia. Conditions there are well documented by Anuak and other local activists (see Gambella Today 2014, for example).

When viewed within the national context of GOE violations of the human right to water but also to health and sanitation, livelihood and freedom from political repression should be viewed within the broader national context. The reality of the GOE human rights violations among its citizens are abundantly documented - in news accounts, policy documents of international aid agencies and heir foreign governments, and numerous websites spearheaded by Ethiopian diaspora groups. These and other sources detail the detention and imprisonment of political dissidents, including journalists, including journalists, scholars, artists and community activists. Summary eviction of rural peoples by the GOE.

Non-governmental organizations (NGOs) and other groups have produced numerous detailed accounts of human rights violations by rights violations by the GOE in the lower Omo basin-reports that directly contradict government accounts. consistently contradict Ethiopian government Human Rights Watch, Survival International, the Oakland Institute, International Rivers, Mursi Online (a website) Oxford University's African Studies Center and the Africa Resources Working Group are among the most active in reporting on-the-ground conditions. Much of the reporting has focused on the Mursi and Bodi peoples who reside well upstream from the Dasanech and Nyangatom along the Omo River (Fig. 1.3), since travel from Addis Ababa and government restriction of independent investigators is less severe in the former. Field based investigation along the southernmost reaches of the Omo River in Ethiopia has become nearly impossible, due to strict government exclusion of independent restrictions. The GOE's allegedly 'voluntary' resettlement and 'community development projects' (CDPs) in the lowermost Omo basin, including those outlined in its Environmental and Social Management Plan for the Gibe III, are challenged by a number of these reports, which instead report citizens' accounts of forced relocation and riverine/delta land expropriation — often imposed with physical force and uniformly with suppression of any dissent.

GOE ministry and Ethiopian Electric Power Corporation (EEPCO) officials have consistently denied any such actions and generally dismiss even the most documented allegations of abuse as simply reflections of "ignorance" on the part of 'foreigners' (even researchers familiar with the area for many years) or a 'colonial' bias against Ethiopia's "national interest" and 'progress' through its Growth and Transformation Program.

Major donor countries, including the United States and the United Kingdom, have sent investigative teams for brief visits to region (especially the Mursi/Bodi region, where major sugar plantation development is advancing). These investigations, dubiously described as 'independent' of GOE influence, have issued only mild criticism of the GOE.

Meanwhile, billions of dollars of international aid continue to pour into the country each year. Much of this is 'direct aid' that is generally unmonitored and easily utilized in support of GOE policies in the lower Omo basin, as detailed in a section below.

\footnotetext{
${ }^{12} 13$ th Annual Pastoralists' Day celebrations, Jinka, South Omo, January 25, 2011.
} 
Hundreds of thousands of northern Turkana residents around the northern and central portions of Lake Turkana and in contiguous upland plains are facing a similar future to that of their northern neighbors, the Dasanech and Nyangatom. The commonality of full-scale livelihood destruction among transboundary ethnic groups, paradoxically, only intensifies cross-border armed conflict among them (Fig. 5.4).

\section{Emerging Human Rights Violations in Kenya's Lake Turkana Region}

$\gg$ The Kenyan state (GOK) is legally bound by the ICESCR treaty to take "deliberate and very specific steps" to ensure the realization of human rights. Yet the GOK's disregard for the Covenant is starkly evident in the Lake Turkana region. Hundreds of thousands of indigenous Kenyan citizens face catastrophic level destruction of their means of survival from the Gibe III and associated developments. Chapter 9 and preceding sections of this book have detailed the mounting livelihood crisis among the northern Turkana. The Kenyan government's roles in these developments and their impacts on the transboundary region range from complicity and active collaboration, in the case of the Gibe III dam and the extensive irrigated farm enterprises, to full partnership as in the case of the Ethiopia-Kenya Eastern Electricity Project (EEHP) - the first phase of the planned Eastern Africa Power Pool (EAPP), funded by international aid (see below).

Despite public statements by the Kenyan government that it has investigated the possible impacts of the Gibe III dam on Lake Turkana and that it has 'negotiated' with the Ethiopian state to "guarantee" the safety of Kenya's indigenous population, the GOK has in fact failed to reach any such accord — which would be entirely unrealistic in any case, given the predictable lake retreat and agricultural enterprises without calling for a halt to the Gibe III dam and its linked development in order to conduct an investigation of such a high magnitude threat to its own citizens.. Instead, the GOK continued with full complicity throughout both planning and construction phases of the dam, without even minimal effort to study the lakeside population or the impacts on it by the predictable lake withdrawal and loss of fisheries.

Years after construction of the project began, the GOK began citing the deeply flawed African Development Bank reports (AFDB 2009, 2010; see Chap. 6) and sent "delegations" to meet with the Ethiopian government - with no reprieve for the Turkana and other ethnic groups residing around the lake.) Quite apart from the GOK's rhetoric about its concern, its insistence on an 'guaranteed artificial flood' to be managed by the GOE and appropriate 'compensation', the GOK failed in virtually all dimensions of such measures. ${ }^{13}$ Moreover, GOK executive offices have clearly overruled opposition and even questioning of the Omo basin developments at all levels of administration; a policy explained to SONT investigators on numerous occasions.

The GOK's demonstrated indifference to the plight of its indigenous population around Lake Turkana is in violation of its 2010 Constitution-particularly Articles 43, 69 and 70; Kenyan national legislation; requirements set by the National Environmental Management Authority (NEMA), as well as the ICESCR. The previous chapters detail how the destruction of pastoral and fishing livelihood among Kenya's lakeside Turkana communities would result from from radical reduction of Omo River flow and lake retreat (see Figs. 5.2, 7.14 and 9.10) - even during what the GOE has described as a "brief" reservoir filling period and despite the 'promised' annual, or "regularized" artificial flood program — a program also repeatedly assured by the GOK, the development banks and their contracted consultants. The extreme improbability of this scenario is detailed in Chap. 6.

Kenyan citizens most affected by the dam and irrigated agricultural enterprises along the Omo River in Ethiopia are not only the hundreds of thousands of Turkana fishers and pastoralists residing around and dependent on the lake's resources, but also thousands of Dasanech settled in Kenya's portion of the Omo delta (see Fig. 1.2) and around the northeastern shoreline of the lake (Fig. 1.3), Gabbra pastoralists along its eastern shoreline, the small El Molo group along the southeastern shoreline, and other pastoral peoples seasonally dependent on the lake for livestock watering and 'last option' grazing (for example, the Rendille).

\footnotetext{
${ }^{13}$ It should be noted that at least two prominent NGOs changed their 'demands' from 'stop the Gibe' to a call for a guarantee of adequate artificial flood (despite clear evidence that an adequate artificial flood was a virtual impossibility and was without precedent in Africa) - in the process of accepting new large external funding. The new funds were in fact forthcoming and neither group lost GOK tolerance of its more limited demands.
} 
Turkana villagers' urgent requests that the GOK stop the threat to the lake from the Gibe III have been sidelined or ignored altogether. Even widespread pleas by northern Turkana fishing communities for GOK support of their fishing rights in the face of Ethiopia-based commercial fishing fleets exploiting Kenya's northern Lake Turkana waters have gone unheeded. Members of the Beach Management Units (government controlled but locally based fisheries management bodies) at Lake Turkana continually complain about the government's refusal to respond to their extreme fear of their livelihood being destroyed by the Omo basin developments - and in immediate terms by the large, Ethiopia based commercial fishing boats taking major catch from the northern reaches of Kenya's lake.

- The GOK failed entirely to inform its vast population in the lake region regarding the actual impacts of the Gibe III and its associated development on their communities, let alone earn for their "free and informed consent," as mandated by the United Nations, the African Union and the GOK itself. Chap. 9 briefly described how "community consultations" with the AFDB's socioeconomic impact assessment consultants were orchestrated events with what were clearly predetermined outcomes. Villagers in two different communities where such 'consultations' were held reported to SONT (South Omo/North Turkana Research Project) researchers that the AFDB 'visitors' gave them assurances that the Gibe III dam would bring major amounts of food, clothing, health care and schooling to their communities. No mention was made of lake retreat or its effects on their fishing, their livestock raising or their households. To the contrary, the consultants repeatedly stressed that the lake "would not be harmed" by the dam. In their written report for the AFDB (in 2009), the socioeconomic consultants stated in their report (AFDB 2009) that their role was to describe the "benefits" of the dam for local communities.

By all accounts, Kenyan police, local government officials and 'translators' were highly intimidating in these meetings (one of which SONT researchers attended.) Despite the consultants' assurances to communities regarding the Gibe III and 'positive' conclusions regarding the socioeconomic impacts of the dam in their report back to the AFDB, the consultants did notate (although inconspicuously in the report's main text-see Chap. 6) extreme anger expressed by village elders over the dam project, which they had learned from other sources would bring destruction to their fishing and livestock raising at the lake.

The exceptionally low quality of information gathering and analysis by the AFDB socioeconomic impact consultants for the Lake Turkana region, combined with their obvious bias (even self described) throughout the process, underscore the assessment's invalidity. There has been no adequate socioeconomic or environmental comprehensive impact assessment of the Lake Turkana region facing extreme crisis.

- A major proportion of Turkana pastoralists and fishers settled in villages along Lake Turkana (see Fig. 9.4 and in nearby lands were either omitted —or in some cases. vastly underestimated-in the GOK's 2009 census. These communities are therefore unlikely in the extreme to be accounted with the dismantlement of their fishing and pastoral from the effects of lake retreat. Those households and communities surviving destruction from lake retreat who do manage to relocate to a town with the hope of receiving assistance are likely to be regarded as drought victims rather than development victims. Given the highly aridic conditions of the region and the immense distances required, few would be able to reach Kenya's international borders to be counted as 'refugees'.

When discussing their situation and their fear of changes to come, comments such as, You will just come across our bones on the land" are commonplace among village elders at the lake. Ironically, these types of comments by the Turkana are also common among their northern neighbors, the Dasanech, with whom they are locked into increasing armed conflict in the face of their equally desperate efforts to survive (Fig. 5.3).

$>$ Fear of Kenya's security forces prevails throughout the northernmost Turkana territory, as these forces are widely known to operate with impunity - including with brutality, in some areas. Although to date, the GOK has not exercised politically repressive measures equal to those of the GOE, the government is intolerant of opposition, whether to the Gibe III development or to the widespread incursion of oil corporations into Turkana lands (see Appendix A). Such threats have caused major curtailment of community voice throughout the area.

- In 2012, Kenya and Ethiopia, along with the World Bank and the AFDB, announced their partnership to build a USD 1.2 billion energy transmission line from Ethiopia to Kenya: the Eastern Electricity Highway Project, or 
EEHP (World Bank 2012a). The Gibe III dam (along with planned additional dams in Ethiopia) was clearly envisaged from the beginning as a source of electricity for the broader Africa region, even though this partnership was announced was six years after the 2006 signing of a Memorandum of Understanding (MOU) between Ethiopia and Kenya for energy export from Ethiopia to its southern neighbor.

The transmission line is designed to extend from Sodo, Ethiopia - a short distance from the Gibe III dam-to a major electricity hub at Suswa, near Nairobi, Kenya (see map in the section below.) After intense negotiations between the two countries over pricing (ESI-Africa 2012), Kenya agreed purchase a continuous supply of $400 \mathrm{MW}$ from Ethiopia-with an arrangement whereby Kenya would pay for all of the agreed upon amount of Ethiopia's hydro-generated electricity, whether or not it uses all of it. ${ }^{14}$

Like the Gibe III dam, the energy transmission system was actually planned years earlier. The World Bank, African Development Bank, key African state executives and international investors have long considered the 45,000 MW hydropower potential of Ethiopia as a 'tower of hydropower' for the broader African region, not just the 'tower of water' extolled by Ethiopia's Haile Selassie (see Chap. 2).

The EEHP constitutes the first phase of a planned power-sharing network throughout eastern Africa-the Eastern Africa Power Pool (EAPP) - a matter detailed further in the next section. The macro plan, in fact, is for an even more comprehensive network of energy systems - one linking entire regions of Africa (World Bank 2012b). This vision is reflected in many documents, among them the $100 \%$ state-owned Kenya Electricity Transmission Company, Ltd. (KETRACO) report on the project, with this comment:

The proposed high voltage transmission line linking Ethiopia to Kenya will form a major part of the interconnection and will serve to close a major gap on the high voltage grid within the Eastern Africa Power Pool (EAPP) countries, because it will ultimately serve as one of the links between Northern and Southern Africa region. (GOK, KETRACO 2012).

KETRACO was incorporated recently - in 2008, with limited liability, for the purposes of establishing a complex, high voltage electricity transmission infrastructure in line with the Kenya Vision 2030 program, building over $4000 \mathrm{~km}$ of transmission lines and establishing linkages for power export to the broader region. The 2012 document cited here focuses on 'mitigation' and resettlement — on the one hand, complying with the Operational and Safeguard policies of the World Bank and AFDB (the chief funders of the Ethiopia-Kenya energy 'highway' project) by conducting such a study, while on the other hand, concluding that mitigation measures, including resettlement and compensation, need be applied only "when feasible".

As in the Ethiopian context, a major gap exists between the Kenyan government's rhetoric concerning the EEHP as servicing Kenya's "national interest" - expressed in GNP growth terms - and "electricity for the poor", on the one hand, and the reality that hydroelectricity transmitted through the 'highway' would be largely purchased by commercial and industrial enterprises as well as middle to upper income groups - not the poorer elements without power, on the other. According to World Bank calculations, the price of electricity (in Kenya as well as Ethiopia) is expected to rise sharply. Certainly the electricity would not benefit the pastoralists and fishers in the Lake Turkana region and north central Kenya-those facing the direct impacts of the EEHP and its electricity supplier, Gibe III dam. Instead, all of the basic needs of the Turkana along the lake will be precipitously decreased or destroyed by the complex of developments.

\section{International Development Bank Collaboration with Human Rights Violations}

While the Ethiopian and Kenyan governments are most immediately responsible for the human rights violations underway in transboundary region, the international development banks - particularly the World Bank and the African Development Bank-have been collaborators in these violations.

\footnotetext{
${ }^{14}$ The agreement was formally concluded between Kenya Power and the Ethiopian Electric Corporation (EEPCO).
} 
$\triangleright$ Actions taken by the World Bank and African Development Bank with regard to the Gibe HI dam and its closely linked developments violate the International Covenant on Economic, Social and Cultural Rights (ICESCR) and other international standards, as well as their own internal operational policies. While the development banks are not under formal obligation to observe United Nations declarations and covenants recognizing specific human rights, they have established safeguard policies and operational procedures consistent with U.N. derived principles (see Chap. 6). World Bank required procedures pertaining to the Omo River basin developments are delineated in the bank's Safeguard Policies and Performance Standards, its Operational Policies series (OP 4.0) and Bank Procedures (BP). These include requirements and procedures concerning environmental and social impact assessment, indigenous peoples, involuntary resettlement, participation and informed consent, and a host of related issues. AFDB safeguard policies largely parallel those of the World Bank.

The cumulative and synergistic effects between the Gibe III dam and dam-dependent irrigated agricultural enterprises along the lower Omo River, as well as between the Gibe III dam and the EEHP, are ignored in development bank assessments, despite the banks' own procedural requirements. Large-scale irrigation systems are calibrated and inflexible systems that depend on effective regulation of the river by the megadam. Previous chapters have documented how their combined radical reduction of Omo River flow volume and inflow to Lake Turkana would compromise already borderline potable water (due to lake salinity) for humans and livestock, eliminate annual flooding of recession agricultural lands as well last resort grazing for livestock, and eliminate a massive proportion of critical fish habitat. The mandate for integral consideration of these developments is explicit not only in the development bank's general operational policies, but also in the specific requirements for considering specific country requests for funding, and in the official interpretations of the ICESCR. The 2010 EIB report, as well as the 2009 and 2010 AFDB impact assessments, are fundamentally flawed in failing to draw these connections - compromising their validity as adequate assessments.

$\triangleright$ The World Bank and the AFDB have repeatedly asserted that they are not involved in the Gibe III dam and associated Omo basin development - a false assertion by any substantive examination of their roles in the complex of development activities. It is true that no direct bank funding was finalized for the Gibe III dam's actual construction, since direct funding was precluded by the GOE's multiple violations of bank operational procedures. Both development banks were reportedly in the process of declining financing requests for the Gibe III by 2010 when the GOE secured alternative funding for dam construction-over USD 460 million from the state-owned Industrial and Commercial Bank of China (see Chaps. 2 and 6). ${ }^{15}$ However, the AFDB and World Bank have supported the Gibe III dam project and its linked developments through a multiplicity of other means.

The two banks' collaboration with the Gibe III dam and its agricultural and electricity export and thus, with the human rights violations accompanying them, include the following activities.

(i) Technical and feasibility studies of hydrodam, irrigation agriculture and energy development potential within Ethiopia, including the lower Omo River basin.

The AFDB, for example, has funded multiple efforts regarding such development, including the more than USD 6 million direct funding for the 1996 Master Plan for development of the 'Omo-Gibe' river basin (Woodroofe \& Associates 1996), as well as its recent impact assessments regarding the Gibe III dam and Kenya's Lake Turkana region (AFDB 2009, 2010). For its part, the World Bank has conducted numerous assessments of Ethiopia's hydropower potential since its first presence in Ethiopia, in the 1950s. It has been active in many aspects of the Gibe III dam's planning and legitimation, despite its preclusion from funding it directly. World Bank explicit support for the project has been explicit, as evidenced in these 2004 comments (notable for their major errors of fact):

- The Omo River is particularly important, both for its large annual flow and its irrigation and hydroelectric potential, and its being one of the principal basins where there is un-likely to be any objection by downstream countries.

- There is no significant use of the Omo River by any other country and the river enters Lake Turkana within the boundaries of Ethiopia. It should, therefore, be relatively easy to negotiate a 'no objection' from Kenya(ibid.)d should that is required for multilateral/bilateral funding. (World Bank 2004)

\footnotetext{
${ }^{15}$ The GOE issued public statements stating that the Ethiopian government 'withdrew' its requests for funding. For a brief time, non-governmental organizations in the U.S. and elsewhere, celebrated what they believed to be a victory when it was clear that development bank funding for the dam did not materialize, when in fact, the project was progressing on several fronts.
} 
(ii) Environmental and socioeconomic baseline studies and impact assessments that exclude identification major human and environmental and social impacts (sometimes through specifications in the Terms of Reference, or scoping, such as in the AFDB 2009 and 2010 assessments) environmental and social-dimensions that are commonly 'defined out' of contract terms of reference (as, for example, in the AFDB 2009 and 2010 assessments (see Chap. 6).

(iii) Active reinforcement or promotion of false information 'justifying' the Gibe III development, including but not limited to the false characterization of (a) the Omo River as causing "disastrous" floods with major loss of human life as well as livestock and property destruction; (b) 'no seismic danger' in the Gibe III region; (c) 'no significant damage or loss of water in Kenya's Lake Turkana, (d) false characterization of the Omo River as only within Ethiopia, when it is clearly a transboundary river, including with part of its active delta within Kenya's national borders-among numerous other examples.

(iv) Planning and funding of the Eastern Electricity Highway Project (EEHP) — a roughly USD 1.3 billion project with major World Bank and AFDB loans, with false assertion of "no relation" to the Gibe III dam (see for example, AFDB 2013). Major coordination and organizational support for the East Africa Power Pool—a major distributional network for EHPP product.

(v) Major financial support for the Ethiopian regime, both the institutions directly engaged in building and managing the Gibe III dam and its linked developments, as well as political repression. This support involves multiple levels of funding, including 'direct aid' (see below).

The Ethiopia-Kenya Eastern Electricity Project (EEHP) is a major electricity export project planned as the first phase of an ambitious multi-nation, integrated power-trading network in eastern Africa-the East Africa Power Pool (EAPP). This project, planned for completion by 2017 (briefly described in the previous section) is an electricity transmission line under construction for $1045 \mathrm{~km}$, from Wolayta Sodo in Ethiopia (near the Gibe III dam) to Suswa outside of Nairobi, Kenya (Fig. 10.1).

Its power carrying capacity of $2000 \mathrm{MW}$ is comparable to the $1600 \mathrm{MW}$ generating capacity of the Gibe III dam. After years of planning the EAPP, the World Bank and AFDB announced their approval of slightly above USD 1.2 billion in finance for the Ethiopia-Kenya transmission and AFDB announced their approval of slightly above USD 1.2 billion in finance for the Ethiopia-Kenya transmission line. ${ }^{16}$ This project cost includes minor funding by the government of France. The total loan package, not including ancillary developments and later measures, was set as follows.

World Bank-USD 684 million (USD 243 for Ethiopia, USD 441 for Kenya)

African Development Bank (AFDB)_USD 354 million

Agence Française de Developpement (AFD)_USD 118 million

The member countries of the EAPP are Ethiopia, Kenya, Tanzania, Uganda, Burundi, Sudan, Djibouti, Rwanda and the Democratic Republic of the Congo (Fig. 10.1).

- The World Bank and the AFDB have repeatedly stated that their funding for the Ethiopia-Kenya transmission line (EEHP) is 'unrelated' to the Gibe III dam-a patently false statement.

To support their claim of 'no connection' between the two projects, the banks point to the approximately 50-km separation between the Gibe III dam and the substation (point of origin) of the Ethiopia-Kenya transmission line at the town of Wolayta Sodo (Fig. 10.2) and contend that the Gibe III dam is not 'necessary' for the economic viability of the transmission line (World Bank 2012b).

In actual fact, electricity generated by the Gibe III dam would inevitably enter the transmission line for export of power to Kenya. The AFDB and the World Bank avoid two realities in making their disclaimers.

In the first place, a $51 \mathrm{~km}, 400 \mathrm{kV}$ connecting line from the dam to the substation at Wolayta Sodo was planned prior to the EEHP announcement, so power generated at the Gibe III was assured for the export system (Fig. 10.2). Construction of the transmission line from the dam to Sodo substation was finalized with $85 \%$ financing from the Chinese EXIM/Export-Import Bank. The banks purport to be free of any involvement in funding the Gibe III project, since GOE procedural violations of

\footnotetext{
${ }^{16}$ Chapter 1 lists the Megawatt (MW) capacity of hydrodams within Ethiopia.
} 


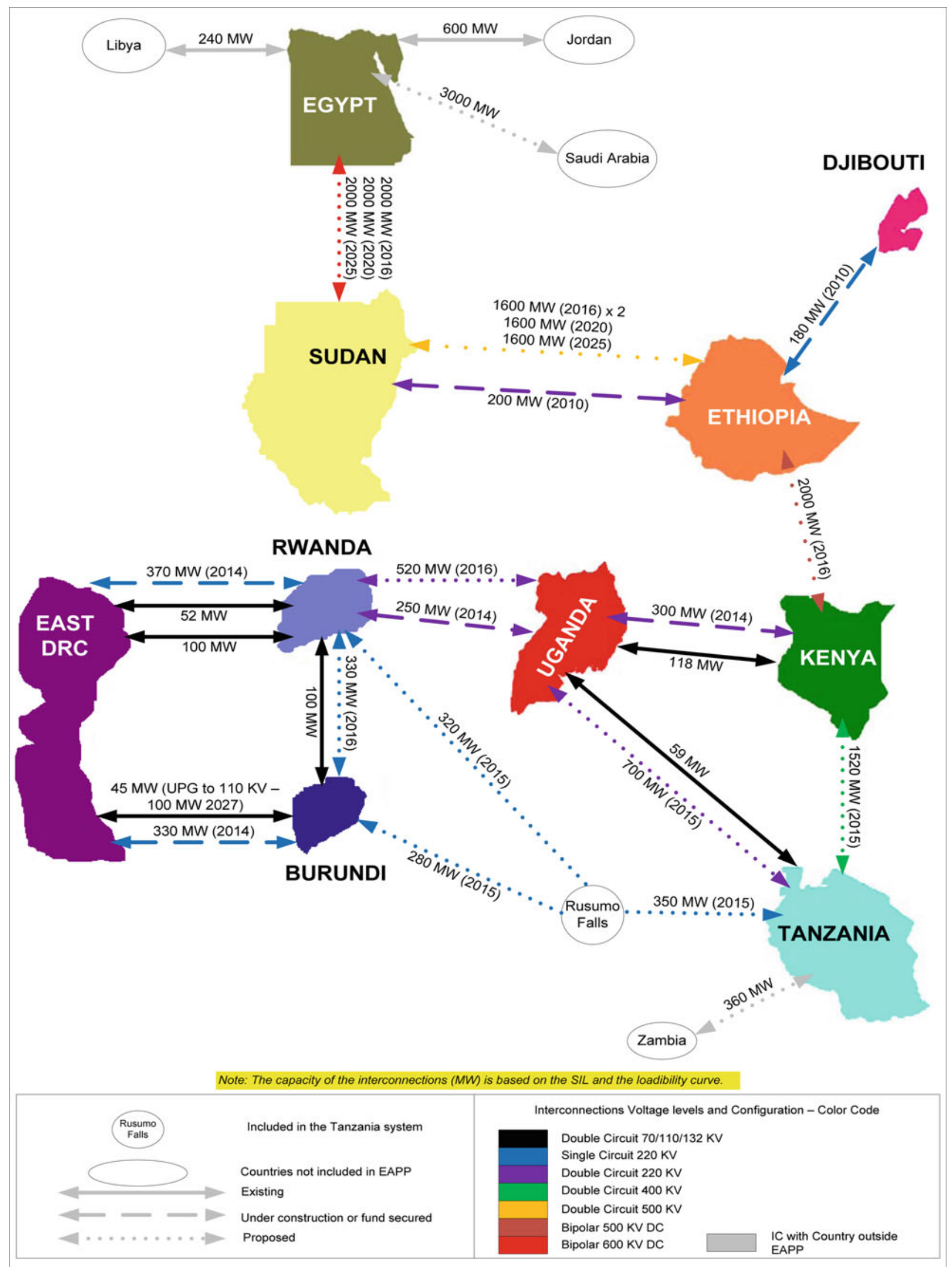

Fig. 10.1 The planned eastern Africa electricity export and distribution system. Source Eastern Africa Power Pool (GOK/EAPP and EAC 2011) 


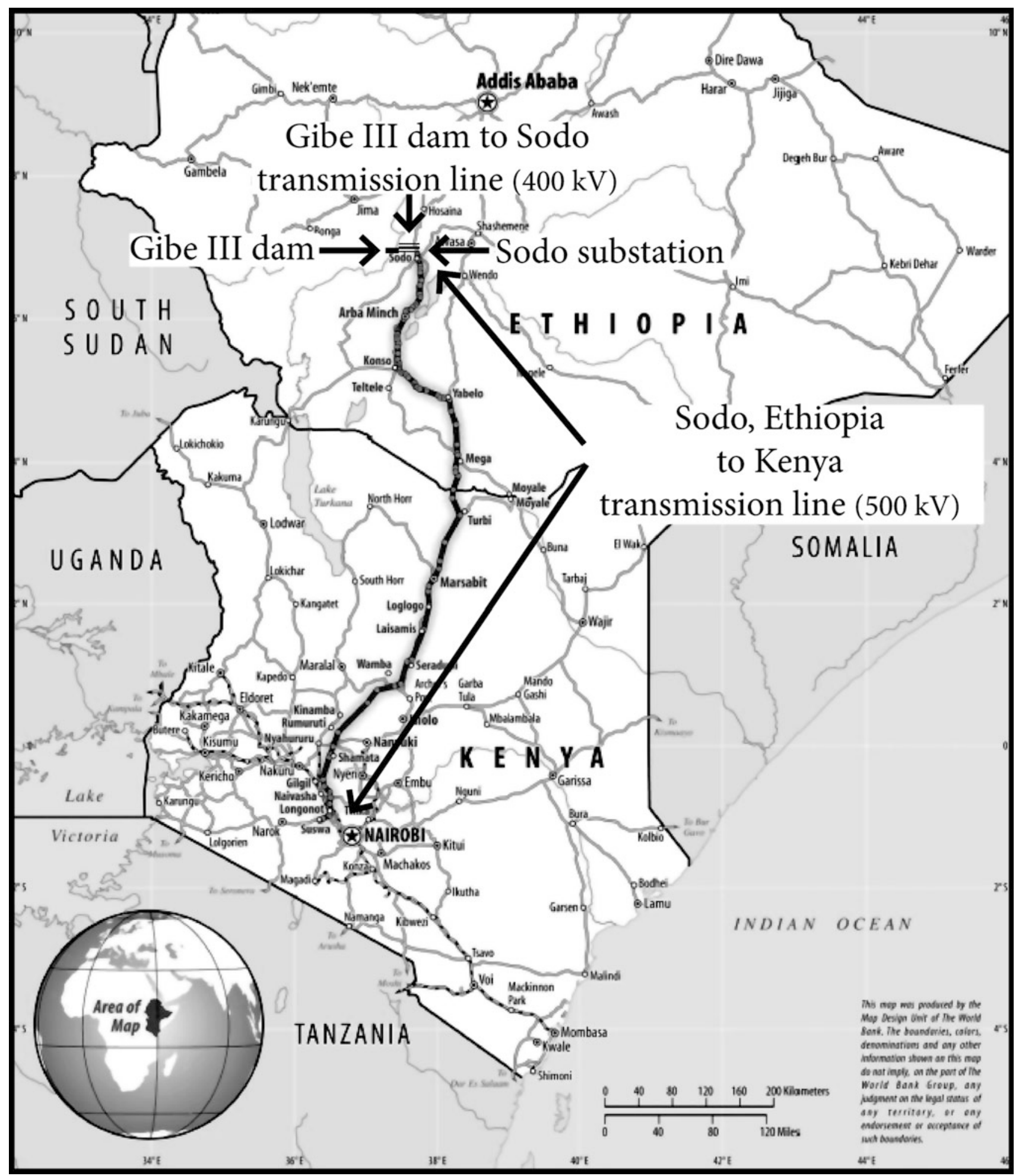

Fig. 10.2 Chinese-financed 51-km transmission connection between the Gibe III dam and the Ethiopia-Kenya Energy Highway Project. Source Base map from World Bank map, reproduced in AFDB Project Appraisal Report (2012b). Labels for Gibe III to Sodo, Ethiopia, and Sodo to Kenya, along with Kenya transmission line labels, added by ARWG 
their procedures prohibited them from such support. The fact that Gibe III electricity would be integrated into both domestic and export transmission systems was known to all agencies involved.

Moreover, the banks have long planned for a major proportion of Gibe III energy to be transported to export markets in Kenya, and beyond. Even prior to the launching of dam construction, the Ethiopian Power System Master Plan update by EEPCO (GOE, EEPCO 2006a) stated the following with regard to the significance of the dam in linking to the export system.

The link starts from Gilgel Gibe-III power plant and passes through Mega substation in Ethiopia and end [sic] at the towns of Nairobi or Eldorate in Kenya. (Fig. 10.2) The link from Gilgel Gibe-III to Mega might be double circuit 400 kV HVAC. HVDC link of at least $500 \mathrm{kV}$ with transfer capacity of about $600 \mathrm{MW}$ is anticipated from Mega substation to Kenya (Nairobi or Eldorate).

- GOE officials have stated that the development banks, in financing the EEHP, insisted that the Gibe III dam be directed to major export markets; government spokespeople have routinely referenced the dam's generated electricity as for export. When specific proportions of Gibe III hydropower slated for export are specified at all, they have generally been 50-60 $\%$. The following are representative of GOE statements on the matter.

- "The objectives of the project are the generation of $1870 \mathrm{MW}$ electric power and enhancing economic integration in Africa through the export of surplus power by erecting a regional interconnection transmission system." ${ }^{17}$ (GOE, EEPCO 2012)

- "The 1870 MW Gibe III hydropower plant is expected to nearly double Ethiopia's current power generating capacity. Ethiopia plans to export a portion of that electricity to Kenya with a power purchase agreement already signed between the two neighboring countries. ${ }^{.18}$ [Aiga Forum 2014]

- "We will definitely have surplus power for export when construction of Gibe III is finalized. It is a matter of only one year... and in order to secure loans for our power projects, we have to export power. When we ask for loans, financiers ask us if we will export power to neighboring countries. Our government subsidies power tariff rate as our people do not [sic] afford to pay. At the local market, the power purchasing power is minimal. So we should support our power development projects by exporting power." 19 [Mihret Debebe, CEO, EEPCO; Emphases added.]

Of particular note is the 2013 statement by the CEO of EEPCO, in 2013:

- "Of the total power generated from Gilgel Gibe III, $900 \mathrm{Mw}$ will be exported to foreign countries, such as Kenya, Sudan and Djibouti. Kenya will get $500 \mathrm{Mw}$, the largest amount of exported power and Gibe III will increase the generation capacity of Ethiopia by $234 \%$ and makes the power export program of the country viable." (Mihret Debebe, CEO of EEPCO, Quoted in Addis Fortune, 2013).

- Kenyan government ofcials have also released numerous statements identifying the Gibe III dam as the major source of their electricity import from Ethiopia. Kenya's fully state-owned Kenya Electricity Transmission Co., Ltd. (KETRACO) was incorporated in 2008 to design, construct and maintain about $4000 \mathrm{~km}$ of transmission lines. The Sodo (Ethiopia) to Suswa (Kenya) line constituted a quarter of this total. KETRACO initiated an assessment of the GIBE III project's environmental impacts on Kenya's resources - a report that minimized the dam's environmental impacts. Like the GOE, EIB and AFDB impact assessments, this GOK assessment was anything but 'independent' of Gibe III development interests. The assessment (ESIA) contract was awarded to the global consulting industry rm, Panafcon-an Africa-focused consulting company that was formed in the early 1990s as a subsidiary of the Netherlands-based global firm DHV International Group of Companies and later bought out by a group of Kenyan investors. ${ }^{20}$ Panafcon is partnered with Italian-based ELC-Electroconsult-itself a major contractor in Ethiopian river basin development. ELC, for example won contracts for Gibe dam projects where it won contracts (along with France based Coyne et Bellier) to represent the GOE in a supervisory role for quality control of the design and construction of the Gibe III.

The United States has recently moved into a key role among multilateral and bilateral promoters of hydroelectricity generation and distribution with in Africa. In its July 2012 'U.S. Position' statement concerning the EEHP, the U.S.

\footnotetext{
${ }^{17}$ News at the government website specifically for the Gibe III project.

${ }^{18}$ Aiga Forum is an Ethiopian government focused website.

${ }^{19}$ Stated in GOE (EEPCO) (Reported in: https://www.thereporterethiopia.com).

${ }^{20} \mathrm{http}: / /$ panafcon.net/index.php/about-panafcon.
} 
Department of Treasury uncritically supported both of the World Bank claims. With the launching of 'Power Africa' by President Obama in 2013, the U.S. took a key role in actively promoting donor groups for launching an unprecedented major system of interconnecting electricity grids, with the EAPP (and therefore, the IHPP) occupying a prominent role. The U.S. role, detailed in its 2015 'Power Africa' report, explicitly demonstrates the operating assumption within the U.S. Executive that developing such electricity networks is intrinsically positive, with no substantive qualification regarding segments of society—and natural resources - that bear the brunt of this development.

$>$ The World Bank and AFDB have major loans to the Ethiopian government in recent years-loans that both reinforce and legitimize GOE policies in the lower Omo River basin and their devastating impacts on transboundary peoples and environments. The two banks have long played a key role in promoting Ethiopia as a 'showcase' country for the 'positive' effects of aid: assistance totaled USD 4 billion in 2014, for example. World Bank loans alone increased markedly to Ethiopia: from USD 988 million in 2010 to USD 1.64 billion in 2014, for example. The AFDB is also a dominant funder - ranking fourth amongst donors. Ethiopia has remained the second highest recipient of Ofcial Development Assistance (ODA) in recent years, garnering about $7 \%$ of the total (OECD 2014). It has also ranked second as a recipient of debt relief in Africa.

Coordinating multi-donor financing — both as general support and as loans for specific projects within Ethiopia—has been a World Bank function since its initial presence there, following WW II. Bilateral agencies including USAID and DFID, along with the EU are also lead funders of the Ethiopian government. Their assistance basically conforms to that of the development banks in 'turning a blind eye' to the GOE's undemocratic, highly repressive policies, while pursuing their own economic, political and military interests. ${ }^{21}$

In view of the geopolitical and economic interests of the major donor nations to the eastern Africa/Horn region and the importance they attach to Ethiopia as a 'partner' in those interests, such studies are likely generated to contribute evidence for the positive nature of such partnership. Consideration of these interests, moreover, also provides at least partial explanation for the 'blind eye' approach to GOE policies both governmental and bank failure to conduct adequate social and environmental impact assessments that address the cumulative and synergistic effects of the Omo River basin and hydroelectric transmission developments.

There are abundant efforts in World Bank and AFDB documents to rationalize their exceptionally high level of nancial and other support for the Ethiopian government. Some of these 'empirical' studies freely incorporate 'rights' language and references to quantitative 'data', implying 'scientific' investigation. The African Development Bank's recently updated study -2004-2013 Country Policy and Institutional Assessment (CPIA) is one of many such efforts (AFDB 2014). The classicatory system designed for this assessment assigns values to five different 'clusters' of policy measures for forty African nations. These 'measures' include social equity, property rights, environmental and social protection and corruption. ${ }^{22}$ Using this system, the AFDB ranks Ethiopia among the highest in the continent- almost across the board. For example, the AFDB concludes that Ethiopia is the top-rated nation for 'Environmental Policy and Regulation', among the top three nations for 'Equity of Public Resource and 'Policies for Social Inclusion/Equity,' and among the top four nations for 'Transparency or Accountability.'

The consistency of gaps between such 'measures' described and conclusions drawn in the 2014 AFDB report, on the one hand, and widely available evidence of social inequity, seizure of property, lack of implementation of regulations and 'protections, lack of transparency and repression of political dissent, on the other, is fundamental and suggests both the arbitrariness of such measures - however quantitatively expressed - and the bank's predetermined design for generating 'evidence' in support of its policies within Ethiopia.

$>$ Much of the international aid to the GOE is allocated as direct budget support, or direct aid—a form of aid largely 'decentralized' and 'unspecied' by donors. Prior to the GOE's no-bid tendering of contracts for the Gibe III dam construction, direct budget support to Ethiopia from major agencies totaled about a third of all aid. Since direct aid is unmonitored by international funders, relying instead on Ethiopia's "self-reporting," this type of aid is highly fungible—and therefore easily used by the GOE to support its preferred policies.

\footnotetext{
${ }^{21}$ U.S. national interests, for instance, involve strong geopolitical, military and investment objectives in the Horn region and the broader East Africa region - in no small part, involving oil and gas and related energy development.

${ }^{22}$ The policy clusters measured (to hundredth values on a scale of 1 to 5) are: Economic Management, Structural (both primarily macro economic measures), Social Inclusion/Equity, Governance and Infrastructure and Regional Integration.
} 
The origin of the direct aid program to Ethiopia rests with the GOE's repressive policies and domestic popular resistance to them. Following social uprisings in 2005-sparked by election corruption and GOE arrests of more than 30,000 people, the 27-member Development Advisory Group (DAG) for Ethiopia suspended funding for the government. The World Bank, AFDB and their partners quickly installed the new 'direct aid' program, a centerpiece of which was the Promoting Basic Services Program (PBS) - for the first years of its existence, termed the Protecting Basic Services Program.

The PBS was launched only months after the DAG suspension was imposed-in 2006, as a multi-donor form of direct aid. In the words of a senior World Bank staff member, as a "creative solution" whereby aid to Ethiopia could be continued despite criticisms of the GOE's repressive policies. In its carefully nuanced statement, the Bank stated, in an interim report (a draft provided to this writer by a World Bank staff member for the Bank's Implementation Status \& Results Report in 2014): In the uncertain environments following a contested general election in Ethiopia in 2006, Development Partners recognized the imperative to continue supporting the Government's significant progress towards achieving the MDGs [Millennium Development Goals] through strengthened decentralized basic services.

Often cited by the development banks and major bilateral agencies as justification for their extraordinary level of nancial support for the GOE, the PBS program - in reality-exemplifies the lack of accountability for billions of dollars received in loans to the Ethiopian government. A little known World Bank report issued in 2012, entitled Diagnosing Corruption in Ethiopia (World Bank 2012c), raised this problem in at least muted terms, but there is no evidence of any impact on the exceptionally strong support for the regime, which continues to be regarded in aid circles as simply "needing improvement." The 'new' PBS program constituted a symbolic change rather than a substantive one and it has been described as such in numerous aid accounts—even within major aid agencies (Knoll 2008). ${ }^{23}$

Dispersal of PBS aid within Ethiopia involves block grants to 'decentralized' political units for "expanding and protecting basic services, or "pro-poor policies," as they are dubbed. These "services" include road-building, "modernization' of agriculture, education, water supply, and payment of local salaries—all under the rubric of "strengthening local financial management systems," supporting local civil society organizations of the GOE's choice, and even - "continuing to develop transparency and accountability" (World Bank 2013). Block grants are issued to ten rural dominated regions within Ethiopia - including the Southern Nations, Nationalities, and Peoples' Region, or SNNPR. which is one of the nine ethnic divisions (kililoch) within Ethiopia and where the lower Omo River basin is located, as noted in earlier chapters.

Phase I of the PBS Program was replaced by Phase II in 2009- the latter version receiving highly mixed reviews even by limited World Bank and AFDB criteria, and finally by Phase III in September of 2012 (activated in January of 2013). when it was both refunded at a higher level and given its present name - Promoting Basic Services. ${ }^{24}$

According to World Bank figures, the most recent approved financing for these programs is as follows.

PBS III-USD 4.887 billion

PBS II-USD 3.364 billion

PBS I-USD 2.562 billion

- The overall PBS regional block grants increased after 2006 and this increase reflected development bank and major bilateral agency support for the GOE. Of the USD 4.88 billion for direct aid to Ethiopia, the World Bank portion is USD 600 million, with terms common to the its 'soft loan' window, the International Development Association (IDA) - that is, 40 year loan terms, with negligible interest a 10 year grace period. AFDB finance terms, issued by its own soft loan window, basically parallel those of the World Bank. While the World Bank and the AFDB are overwhelmingly dominant in aid PBS funding (as in Ethiopia's aid portfolio overall), the U.K.'s DFID has been a major contributor among the bilateral agencies_-providing more than $£ 740$ million in support. ${ }^{25}$ Other co-financers of Phases II and/or III, although

\footnotetext{
${ }^{23}$ Knoll (2008) details the PBS program within the context of 'budget support' in African aid more generally, as it unfolded from the mid 1990s. ${ }^{24}$ Unless otherwise specified, information regarding the development bank expenditures for the PBS programs are drawn from reports by the AFDB (2012a) and the World Bank (2013, 2014), as well as annual reports.

${ }^{25}$ Major political pressure has been exerted on DFID by non-governmental organizations (e.g., Survival International and Human Rights Watch) to terminate its funding for the PBS III program. This pressure has been largely fueled by HRW (and other) reports concerning the GOE's eviction and political repression policies in the Gambella region (see below)
} 
much smaller contributors, are the European Union and the bilateral agencies of Austria, Italy, Ireland, Canada, Spain, Germany and the Netherlands. While not a direct contributor to the PBS III, the United States remains the largest bilateral donor to Ethiopia. ${ }^{26}$

All aspects of the PBS are implemented at the discretion of the GOE, without effective oversight-in spite of periodic development bank public assurances of 'independent' evaluation. A 2013 analysis of PBS program funding and GOE human rights violations by Inclusive Development International (IDI 2013) quotes one World Bank officer's disclaimer regarding the GOE's usage of funds:

"The PBS itself has no direct mechanism to influence choices made at the local government level.

- The SNNPR receives a substantial amount of the PBS III funds and program support, which is readily used by local officials for a multiplicity of activities that further the major impacts on not only Ethiopia's lowermost Omo River Basin population, but also on the major population residing around Kenya's Lake Turkana. These GOE activities include: road building and other infrastructural construction, for political structures and security apparatus, expropriating resources of indigenous communities, and serving the needs of the large commercial plantations that replacing indigenous communities. In the name of "decentralized development"-effectively unmonitored, PBS funds can be used for the eviction process itself and the political repression that accompanies it.

AFDB and World Bank appraisal documents make frequent assertions of the PBS Program's "success." Such statements are explicit in the AFDB's (2012a) PBS appraisal, for example:

"The 84.3 million citizens of Ethiopia will be the main beneficiaries of the PBS III program. The direct beneficiaries will be the citizens in woredas from 10 regions that receive federal block grants."

The report continues with a summary dismissal of PBS: "The programme has been classified under category III and is not expected to have any negative environmental impact."

Such blatant exclusion of even the possibility of environmental and social negative outcomes of the program, let alone highly probable and disastrous ones, has avoided triggering of development bank Safeguard and Operational Policy procedures. The development banks (and large bilateral agencies) steadfastly maintain the rhetoric of an "in place accountability mechanism" for the PBS program and insist that the programs are for the "promotion of civil society organizations" and the "engagement of civil society."

The reality, however, is altogether different. The 'Social Accountability' sub-component of PBS III is under the control of the GOE's Ministry of Finance and Economic Development (MOFED) — one of the key ministries directly promoting the Omo River basin developments. 'Participating' civil society organizations (CSOs) are selected by the GOE, so only those conforming to government policies are selected. This is even true for 'independent' auditing of PBS policies, the results of which are submitted to the banks for their appraisal. Predictably, bank appraisers of this direct aid are generally complicit with their client institutions' perspectives. So-called 'external' peer reviewers selected by the AFDB for its PBS III Project appraisal, for example, were selected from three other PBS funding agencies- the World Bank, DFID and Irish Aid. ${ }^{27}$

- Human Rights Watch produced a report on the PBS program (HRW 2012a) focusing on the relatively more accessible Gambella region of western Ethiopia, where strong local resistance to major expropriation and political repression has transpired and an active Anuak diaspora-based organization (the Anywaa Survival Organisation, or ASO) has been effective. The HRW report underscores the World Bank's failure to consider its responsibility for the debacle underway there, even by the Bank's own internal procedural requirements. The Gambella accounts underscore the seriousness of

\footnotetext{
${ }^{26}$ For details regarding U.S. assistance, see the U.S. State Department, USAID and CIA websites; also see Oakland Institute (2013).

${ }^{27}$ The measures used for assessing the PSB are comparable to those used for Ethiopia's general economic advancement of GTP and MDG goals namely, aggregate and per capita indicators - but applied to the regional level. Data for regional level 'services delivered,' 'infrastructure constructed', water resource developments undertaken, local personnel newly salaried, and so forth exclude on-the-ground realities and certainly the matter of who 'benefits' and who bears the 'costs' of the GOE's development actions - in the SNNPR, the Dasanech, Nyangatom, Kara, Bodi, Mursi and neighboring indigenous peoples in the lower Omo River basin.
} 
this problem as it applies to the less documented crisis unfolding in the lowermost Omo basin within the SNNPRcertainly, in the for the Dasanech and Nyangatom region. ${ }^{28}$

Specific reports on the SNNPR PBS III and related projects, including the 'One Water, Sanitation and Hygiene National Program (OWNP) in the region reflect such omission and misrepresentation. The OWNP (the 'ONE WASH' program) is the world's largest sector-wide approach (SWAP) to 'Water, Sanitation, and Hygiene (WASH) — sponsored by UNICEF and extolled as a major "success" already in 'achieving' Ethiopia's Growth and Transformation Program and MDG goals. The recent OWNP social assessment report, written on behalf of the Ministry of Water Resources (GOE, MOWR 2013), is illustrative of the bias at play. ${ }^{29}$ While identifying the 'Dassench' [sic] Woreda district as having a human population of more than 56,000, with the 'Dassench' constituting more than $97 \%$ of that number, the report barely mentions "traditional water resource management" and "recession agriculture" and makes mention of the Gibe III dam or irrigated agricultural schemes and their full-scale impact on the region's water resources.

While the OWNP assessment outlines what it terms "progress" underway from the program, the reality of tens of thousands of indigenous residents being evicted and expropriated with collapse of their livelihoods already underway, is omitted altogether. Such reporting, if not directly unethical, is irresponsible in the extreme and reinforces the massive scale human destruction already beginning to manifest in the region due to the Gibe III dam and its linked developments. ${ }^{30}$

\section{$>$ The World Bank commonly objects to complaints regarding their human rights record-in general as well as within} Ethiopia-as well as their 'obligation' to observe U.N. recognized human rights, in two ways.

Firstly, the Bank refers to its own Articles of Agreement (Sect. 10) that define it as a "non-state actor," meaning that it should not "interfere in the political affairs of any member state."

Secondly, the Bank contends that while demands for it to observe human rights are issued in the abstract, the specifics of exactly how it might implement such concerns remain vague.

With regard to the first assertion, it is true that international law applies only to individual states. A considerable literature and discourse has emerged, however, which leads to a different interpretation of non-state actors and internationally recognized human rights - namely, one whereby the development banks should be held accountable. ${ }^{31}$

The past thirty years have witnessed repeated clashes between the World Bank and civil society organizations from both 'developed' and 'developing,' (or Global South) countries with respect to the human rights dimensions of bank policies. The World Bank's elaborate set of Standards and Operational Policies-largely replicated in the regional development banks, including the AFDB — are now challenged at a far more detailed and informed level.

Regarding the Bank's second contention - that human-rights concerns are generally formulated only in abstract terms, the human rights issues in the developments impacting the peoples of the lower Omo River Basin and Lake Turkana region are certainly not abstract. They center upon the denial of ICRCS recognized rights for hundreds of thousands of indigenous peoples - one articulating with the violation of rights to health, livelihood and freedom from political repression.

Because the World Bank and AFDB have actively collaborated in (and have even encouraged, with funding and promotional activities) Ethiopian and Kenyan governmental human rights violations in the transboundary region, informed challenge to the banks' breach of their own Safeguard and Operational Policies is entirely appropriate.

\footnotetext{
${ }^{28}$ The World Bank has responded to non-governmental and other protest of its PBS support for the GOE's policies in Gambella, with an Inspection Panel investigation. Released in November, 2014, the Bank's report was equivocal and fragmentary (World Bank 2014b), and was countered by NGO critics (including Human Rights Watch and IDI).

${ }^{29}$ This social assessment was carried out with the support of U.K.'s DFID.

${ }^{30}$ An April, 2014 AFDB assessment of the 'One Water' program notates (in its summary tables and briefly in text) the issue of 'dam' development (without mention of the Gibe III), and even "adverse impacts of pastoral water supply systems" in general. The points remain abstract ones, however, so its omissions and misrepresentations largely parallel those of the GOE's ministry report.

${ }^{31}$ See for example the writings of Skogly (2001), Ghazi (2003), Alston (2005) and Clapham (2005). Moreover, the U.N. Committee on Economic, Social and Cultural Rights (CESCR), described earlier in this chapter, in its General Comment No. 14, asserted that non-State actors were obligated to observe the international human right to health (Coomans 2007).
} 


\section{The Stark Policy Choice: Catastrophic Level Destruction or Sustainable Development Within a Human Rights Framework}

If the Ethiopian and Kenyan governments continue their present course of violating internationally defined human rights, particularly those recognized in the International Covenant on Economic, Social and Cultural Rights Treaty (ICESCR), their actions may well be regarded as criminal.

$>$ The crisis unfolding in the Ethiopia-Kenya-South Sudan transboundary region is fundamentally one of policy objectives and accountability. Ethiopian government and international development bank officials have consistently described the purpose of the Gibe III dam and its associated developments as "essential" to Ethiopia's "national interest" and its 'growth and transformation' program and Ethiopia's electrification needs, including electrification for the "rural poor." Yet the on-the-ground effects of this development in the lower Omo basin and Lake Turkana region-already in evidence during the early phases of this development - suggest the makings of a humanitarian crisis with massive scale hunger and vulnerability to disease, cross-border inter-ethnic armed conflict, major government expropriation and political repression of citizens, and irreversible environmental destruction — outcomes that can hardly be regarded as 'progress.' Despite these predictable effects already emerging in the transboundary region, however, both government and bank statements continue to label the development a sure 'success,' based on GNP and per capita income, energy and other projections for the nation as a whole. ${ }^{32}$ Sorting out the differences between such macro level projections and ground level realities for the half million citizens struggling to survive in three-nation transboundary area is key to a rational discourse concerning the economic and political future of the region.

At the most general level, the policy choice is an unambiguous one. Either continue along the present road to social and natural resource devastation - a road rife with human rights violations-or bring a halt to the destruction underway in order to initiate a new pathway for action-one consistent with internationally recognized human rights and geared to creating a sustainable future for the peoples of the transboundary region as well the three nations involved.

Continuing along the present road is an unacceptable option by any measure of project outcomes that includes the transboundary region's indigenous peoples. Even if the alternative pathway defined above were to be pursued, major questions emerge as to how to proceed. For example, how is it possible to take account of the increasingly desperate survival needs of the pastoral, agropastoral and fishing peoples in the transboundary region that is most impacted by the development, while simultaneously addressing the aspirations of citizens in the region as a whole?

Although insufficient as full answers to this question, two matters require immediate attention if a solution to this challenge is to be constructed.

First of all, there is legal imperative for action. Based on violations of human rights in the transboundary region-rights recognized by the ICESCR that must be restored. This requires restoring indigenous communities' access to food and the necessary means to produce it as part of their right to an adequate standard of living. Compliance with the ICESCR is not a choice - it is a legally binding treaty.

This action could be accomplished with at least a temporary suspension of the plans for Gibe III hydrodam electricity generation, an end to the withholding of downstream river flow and the reinstatement of Dasanech and Nyangatom communities to their lands and resources along the Omo River. Reinstatement of the Omo River's flow would allow inflow to Lake Turkana, bringing at least temporary reprieve to hundreds of thousands of pastoralists and fishers depending on the lake's resources. Such a suspension should trigger at least a pause in temporary suspension of large-scale irrigated plantation construction as well, while an acceptable future scenario is being constructed.

\footnotetext{
${ }^{32}$ Because of the high capital outlay for major dams, the international development banks are by far the key funders and coordinators of these developments. See Chap. 2 for a history of river basin development within Ethiopia — dubbed by Emperor Haile Selassie himself as the water tower of Africa.
} 
Restoration of the specific human rights involved should also be a triggering force for major evaluation and assessment of the Gibe III dam and its linked developments which were never responsibly dealt with by the Ethiopian or Kenyan governments, nor by the international development banks that have substantively backed the development from early planning phases to the present.

- Given the actions already taken by the Ethiopian Government, it is most unlikely that the GOE would cease its human rights violations of its own accord or even pause its headlong pursuit of the Gibe III dam and its linked developments. Their reversal of these actions would be even less likely following the inception of actual electricity generation at the dam. Interruption of the human rights abuses and humanitarian disaster unfolding in the transboundary region, coupled with the GOE's prohibition of independent 'eyes-on-the-ground' in the lowermost Omo basin and its policies of political repression would almost certainly require leverage by external institutions

- The reality is that the World Bank and the AFDB, along with other major aid agencies and their donor states, have such leverage and could exert it by taking any of a broad range of action, including include withholding of funds allocated, imposition of 'conditions' for new project lending or continued institutional support, and a host of other political and economic measures. The fact that major donor countries have strong economic interests (in oil and gas development, for example) and geostrategic objectives of in the region, however, and their political judgment that supporting the present Ethiopian regime adequately serves those interests suggests that any leverage applied by them would require substantial pressure from their own public constituencies.

Secondly, in-depth and accurate information in the form of environmental and socioeconomic baseline studies or impact assessments (EIAs, or ESIAs) for the Gibe III dam and its linked developments are essential to sound decision making regarding the future of the region's peoples and environments. Both national governments and development banks, however, have failed to make any such effort — in breach of international standards, the two countries' Constitutions and domestic laws and the development banks' own operational principles. In addition to the pressing human rights violations requiring attention, two required ESIA failures - even considered individually-merit leveraging a suspension of Gibe III dam, irrigated agriculture and energy transmission line completion and operationalization, at least until such time that they are resolved. (See Chaps. 2 and 6 for detailed discussion).

- The Gibe III dam and its closely linked developments have clear transboundary impacts, so any adequate environmental and socioeconomic impact assessment (ESIA) must be conducted within transboundary framework. None of the assessments produced - by either African government, the EIB or the AFDB, have produced such an ESIA. Instead, all assessments have addressed only fragments of the impacts requiring attention and even these with multiple failings (see Chap. 6) and only for Ethiopia or Kenya. It is striking that the predictable negative impacts of the Gibe III project are strongest in the tri-nation border region - the area most neglected in all reports. All assessments done by the governments and development banks have addressed only fragments of the region's environmental and social dimensions concerns in one or another country, despite the fully verifiable transboundary character of the project, not to mention the reality that the strongest impacts are in the border region of Ethiopia, Kenya and the Ilemi Triangle/South Sudan. ${ }^{33}$

- The cumulative and synergistic impacts of all three components of development must be dealt with as one unitary system. The Gibe III dam has been documented in preceding chapters (as well as by Oxford University scholars and several NGOs cited earlier) as having cumulative effects with the irrigated agricultural enterprises along much of the Omo River downstream from the Gibe III dam. The Gibe III's linkage with the energy highway system from Ethiopia to Kenya (the EEHP) is documented in the previous section, World Bank and AFDB statements to the contrary notwithstanding.

$>$ Considering two internationally established commitments by States-namely, to protect ICESCR recognized human rights (including the right to food, an adequate standard of living, and water) and to promote environmentally and socially sustainable development-questions inevitably arise as to who actually controls environmental and socioeconomic impact assessments and related studies, and who participates in them.

\footnotetext{
${ }^{33}$ Ironically, all the ethnic groups in the region-although excluded from substantive participation in the assessments produced (GOE 2009a, 2009b; EIB 2010; AFDB 2009, 2010) conduct their lives with full cognizance of transboundary social and environmental dy live their lives with full cognizance of transboundary social and environmental dynamics.
} 
- It has become commonplace among development specialists and researchers with extensive field-based experience in some bilateral aid agencies (particularly in Scandinavia) and non-governmental organizations to regard cooperative investigation with communities as essential to the production of accurate, thorough and useful analysis of a region's socioeconomy and environmental status, as well as identification of the local residents' most pressing needs. Multiple forms of community/investigator cooperative approaches to considering livelihood systems, natural resource use patterns in relation to possible development (or conservation) policies have transpired in ways that actually assist communities in improving their life circumstances, rather than undermine them.

Local communities likely to be most affected by the development in question need to be included as active participants in all phases of impact assessments and related studies, including:

-identifying the socioeconomic and environmental parameters, or 'bounding' of the task at hand,

- gathering information and data (field derived components, at least), with ongoing interpretation, and

- drawing conclusions and summarizing the key issues derived from the effort, including their significance for the

future of local communities and their environment.

Much has been learned about cooperative processes between external investigators and local communities that increase accurateness of results. In pastoral and agropastoral contexts, for example, it is clear that local participants need to be selected through dialogue with traditional leaders, rather than government appointed ones. Broad-based and community-held discussions are a critical component and these need to be held in all phases of the work and throughout the geographic area being considered. At community gatherings, local participants, including community leaders, male and female elders and both genders of youth need to actively engage in the above dimensions of the collective effort. Those community members involved in core roles of the investigation have a major roles in planning items for open community discussion and community feedback, while working closely on a daily basis with external investigators. The results from open meetings (as well as from 'feedback surveys', etc.) need to be incorporated into the final assessment, or report-including its summary and conclusions. Results and conclusions need to be made presented to communities prior to releasing them to policymakers and client institutions. Finally, all such documents must be fully transparent and available to the public.

Constructive baseline studies and environmental/socioeconomic impact assessments (ESIAs) and the like need to be unrestricted in their ability to question the project or development approach in question, based upon its findings. This contrasts sharply with the existing arrangement for the Omo basin projects detailed in Chap. 6, for example, where implementation of the project is presumed to be a result of the ESIA - a situation permitting opportunity only for 'suggested' after-the-fact mitigation or monitoring actions, or additional studies, while the project moved to completion. The Gibe III assessment scenario, unfortunately, is indication of the predominant pattern in assessment related study contracting - one involving major 'reciprocity' and 'revolving door' relationships.

\section{- Changes in both perspective and method of this order obviously necessitate a significant shift in accountability} relations. Clearly, investigators have some basic accountability to those who contract them. Yet to assure a cooperative outcome, with accuracy of the work produced, they must also have genuine accountability to local communities which have sufficient authority to ensure that the content and outcomes of investigation represent the realities of their lives and their environments, and authority to guarantee that their voice will be heard well beyond their immediate localities-in fact in the distant offices of policymakers and politicians. It should be clear that global consulting industry corporations and individuals - parties well-equipped and experienced in accepting accountability only to their client institutions in a system that amounts to a 'contract treadmill' and too often, a 'complicity treadmill' involving very large sums of money, are ill-equipped for such an orientation.

- A participatory, community-inclusive approach to studies and impact assessments for consideration of development programs is best implemented by non-governmental organizations, academics (research units or groups, individuals), relatively small consulting organizations, rather than by global consulting industry representatives. Lead investigators should be able to demonstrate qualifications including:

- In-depth familiarity with the geographic region concerned, including with substantive field-based experience in the region or one closely paralleling it.

-Appropriate professional training credentials in socioeconomic or human ecological (broadly defined) fields.

-Experience and commitment to studies weighted to field-based investigation rather than 'desk studies' with utilization of available printed information, etc., and brief field 'visits'. 
—A clear and demonstrated record of genuinely participatory work with local communities.

-Absence of financial contracts or agreements with governments, development agencies or private firms engaged in any substantive way with the project or program under consideration - for example, for a five-year period. Additional participants in studies, such as technical experts (e.g., for seismic, geological, hydrologic, agricultural or cultural studies) should to be held to the same standard.

- Full public transparency of funds received for study and the major parameters of the study underway.

$>$ The approaches outlined above for impact assessment and related investigations a may well be objectionable to in mainstream development circles, as "impractical" and "unachievable" in remote areas and among culturally traditional peoples. To the contrary, there are plentiful accounts by seasoned investigators and aid practitioners that support the conclusion that communities in highly remote and marginalized contexts are not only receptive to genuine inclusion in such processes that help determine their own future-their participation is in fact essential to the success of development or conservation planning with equitable and sustainable objectives.

Such understanding is long overdue in major agencies and government policymaking offices.

Changing the course of existing development and broader social policies directed to the Ethiopia-Kenya-South Sudan transboundary region offers the possibility of sparing the lives and livelihoods of hundreds of thousands of citizens and rethinking the region's social and environmental future within a human rights framework. Embracing humane and sustainable development prospects for upcoming generations in eastern Africa remains a possibility—even at this 'eleventh hour.'

\section{Literature Cited}

African Commission for Human and Peoples' Rights (ACHPR). 2004. http://www.achpr.org/about/achpr/.

African Commission for Human and Peoples' Rights (ACHPR). 2015. Resolution on the Right to Water Obligations - ACHPR/Res.300. http:// www.achpr.org/sessions/17th-eo/resolutions/300/.

African Development Bank (AFDB). 2009. A. S. Kaijage, N. M. Nyagah, Report, socio-economic analysis and public consultation of Lake Turkana Communities in Northern Kenya. Tunis.

African Development Bank (AFDB) 2010 (Nov.), S. Avery, Assessment of Hydrological Impacts of Ethiopia's Omo Basin on Kenya's Lake Turkana Water Levels, Final Report, 146 pp.

African Development Bank (AFDB), African Development Fund. 2012a (July). Ethiopia. Promoting Basic Services Programme (PBS III). Appraisal Report/.

African Development Bank (AFDB). 2012b (Sept). Ethiopia-Kenya Electricity Highway. Project Appraisal Report. 41 pages.

African Development Bank (AFDB). 2013 (July 5). AfDB launches \$ US 1.26 billon Kenya-Ethiopia Electricity Highway. http://www.afdb.org/ en/news-and-events/article/afdb-launches-us-1-26b-kenya-ethiopia-electricity-highway-11733.

African Development Bank (AFDB). 2014 (Apr). 2004-2013 Country Policy and Institutional Assessment (CPIA). http://www.afdb.org/en/ documents/project-operations/country-performance-assessment-cpa/country-policy-and-institutional-assessment-cpia/.

Africa Resources Working Group (ARWG). 2009 (Jan). A Commentary on the Environmental, Socioeconomic and Human Rights Impacts of the Proposed Gibe III Dam in the Lower Omo River Basin of Southwest Ethiopia. http://www.arwg-gibe, 29 pages.

Aiga Forum. 2014 (June 12). Ethiopia to fill Gibe III dam, rejects renewed calls for halt. http://aigaforum.com/news/gibe3-news-061214.php.

Alston, P. (Ed.). 2005. Non-State Actors and Human Rights. Oxford: Oxford University Press.

Carr, C. J. 2012 (Dec). Humanitarian Catastrophe and Regional Armed Conflict Brewing in the Border Region of Ethiopia, Kenya and South Sudan: The Proposed Gibe III Dam in Ethiopia, Africa Resources Working Group (ARWG). https://www.academia.edu/8385749/Carr_ ARWG_Gibe_III_Dam_Report, 250 pages.

Clapham, A. 2005. Human Rights Obligation of Non-State Actors. Oxford: Oxford University Press.

Coomans, F. 2007. Application of the International Covenant on Economic, Social and Cultural Rights in the Framework of International Organisations. In: von Bogdandy and Wolfrum, R. (Eds.), Max Planck Yearbook of United Nations Law, Vol. 11, 359-390. Koninklijke Brill N. V.

ESI-Africa. 2012 (Jan 23). Kenya and Ethiopia sign power purchase deal. ESI-Africa.com.

Ethiopia, Government of (GOE), Ethiopian Electric Power Corporation (EEPCO). 2006. Ethiopian Power System Master Plan.

Ethiopia, Government of (GOE), (Ethiopian Electric Power Corporation). 2009a. CESI and Mid-Day International Consulting Engineers 2009, Gibe III Hydroelectric Project, Environmental and Social Impact Assessment, Report No. 300 ENV RC 002C.

Ethiopia, Government of (GOE), Ethiopian Electric Power Corporation (EEPCo). 2009b Agriconsulting S.p.A. and Mid-Day International Consulting 2009 , Level 1 Design, Environmental and Social Impact Assessment, Additional Study of Downstream Impacts. Report No. 300 ENV RAG 003B. 
Ethiopia, Government of (GOE), Ethiopian Electric Power Corporation (EECPO). 2009c. Salini MDI Consulting, Environmental and Social Management Plan.

Ethiopia, Government of (GOE), Ethiopian Electric Power Corporation (EEPCO). 2012 (April), Gibe III News http://www.gibe3.com.et/EEPCo. html

Ethiopia, Government of (GOE), Ministry of Water Resources (MOWR). 2013. Social Assessment of the Water Supply, Sanitation and Hygiene Program-OWNP. Ethiopia. http://www.mowr.gov.et.

Ethiopia, Government of (GOE), Ministry of Foreign Affairs (MoFA). 2014 (April). The Fifth and Sixth Periodic Country Report (2009-2013) On The Implementation Of The African Charter On Human And Peoples' Rights In Ethiopia. Addis Ababa.

European Investment Bank (EIB). 2010 (Mar). Sogreah Consultants, Independent Review and Studies Regarding the Environmental \& Social Impact Assessments for the Gibe III Hydropower Project. Final Report, 183 pages.

Gambella Today. 2014. Ethiopia: Lives for land in Gambella.

Ghazi, B. 2003. The IMF, The World Bank Group and the Question of Human Rights. Transnational Publishers.

Hall, R.P., B. Van Koppen and E. Van Houweling. 2014. The Human Right to Water: The Importance of Domestic and Productive Water Rights. Sci Eng Ethics (2014) 20:849-868.

Human Rights Watch (HRW). 2012a (Jan). Waiting here for death: Forced Displacement and "Villagization" in Ethiopia's Gambella Region. www.hrw.org, 13 pages.

Human Rights Watch (HRW). 2012b. What will happen if hunger comes? Abuses Against the Indigenous Peoples of Ethiopia's Lower Omo Valley. www.hrw.org, 91pages.

Human Rights Watch (HRW). 2013. Abuse-Free Development. How the World Bank Should Safeguard Against Human Rights Violations. http:// www.hrw.org. 60 pages.

Human Rights Watch (HRW). 2014a (Feb. 18). Ethiopia: Land, Water Grabs Devastate Ethiopia. https://www.hrw.org/news/2014/02/18/ethiopialand-water-grabs-devastate-communities.

Human Rights Watch (HRW). 2014b. World Report: Ethiopia. https://www.hrw.org/world-report/2014/country-chapters/ethiopia.

Inclusive Development International (IDI). 2013 (Oct). Human Rights and the World Bank Safeguards Review: Lessons from Ethiopia. Forced Villagization and the Protection of Basic Services Project. www.inclusivedevelopment.net.

Kenya, Government of (GOK), Eastern Africa Power Pool (EAPP) and East African Community (EAC). 2011. SNC Lavalin, Final Master Plan Report Vol. IV. Regional Power System Master Plan and Grid Code Study.

Kenya, KETRACO (Kenya Electricity Transmission Company Limited). 2012 (Jan). Proposed Ethiopia-Kenya Power Interconnection Project. Final Environmental and Social Impact Assessment (ESIA) Report.

Knoll, M. 2008. Budget Support: A Reformed Approach or Old Wine in new Skins? UNCTAD/OSG/DP/2008.5.

Knox, J. 2014. United Nations Mandate on Human Rights and the Environment. http://srenvironment.org/tag/un-mandate/.

Oakland Institute. 2013. Overlooking Violence, Marginalization, and Political Repression. http://www.oaklandinstitute.org.

Organisation for Economic Co-operation and Development (OECD). 2014. http://www.oecd.org/countries/ethiopia/aid-at-a-glance.htm.

Skogly, S. 2001. The Human Rights Obligations of the World Bank and the International Monetary Fund. Cavendish Publications.

Survival International. 2013a (Mar 24). Concern mounts over humanitarian crisis in Lower Omo, Ethiopia. http://www.survivalinternational.org/ news/10094.

Survival International. 2013b (Apr 15). Aid agencies turn blind eye to 'catastrophe' in Ethiopia. http://www.survivalinternational.org/news/9125.

Survival International. 2013c (Nov 27). Top human rights watchdog investigates Ethiopia and Botswana. http://www.survivalinternational.org/ news/9777.

Survival International. 2014. The Omo Tribes. http://www.survivalinternational.org/tribes/omovalley/gibedam

United Nations, General Assembly. 2007. The U.N. Declaration on the Rights of Indigenous Peoples (UNDRIP).

United Nations, General Assembly. 2010 (July 28). Resolution GA Res 64/292. The human right to water and sanitation. http://www.un.org/en/ga/ 64/resolutions.html.

United Nations, OHCHR and UNEP. 2012. Human Rights and the Environment. Joint Report. http://www.unep.org/environmentalgovernance/ Portals/8/publications/JointReport_OHCHR_HRE.pdf.

United Nations, Committee on Economic, Social and Cultural Rights (CESCR) 2002 (Nov). General Comment No. 15, The Right to Adequate Food. http://www.refworld.org/docid/4538838c11.html

United Nations, Committee on Economic, Social and Cultural Rights (CESCR) 2002 (Nov). General Comment No. 15, http://www.unhchr.ch/tbs/ doc.nsf/0/a5458d1d1bbd713fc1256cc400389e94.

United Nations, Office of the United Nations High Commissioner for Human Rights (OHCHR). 2012. Human Rights Treaty System: An introduction to the core of human rights treaties and the treaty bodies. Fact Sheet No. 30. http://www.ohchr.org/Documents/Publications/ FactSheet30Rev1.pdf.

United Nations, General Assembly. 2013 (Dec). The human right to safe water and sanitation. Resolution A 68/157. http://www.un.org/en/ga/ search/view_doc.asp?symbol=A/RES/68/157.

United States, USAID. 2015. Power Africa. https://www.usaid.gov/powerafrica.

Winkler, Inga. 2012. The Human Right to Water: Significance, Legal Status and Implications for Water Allocation. Hart Publishing, Oxford and Portland, Oregon.

Woodroofe, R. \& Associates, with Mascott Ltd. 1996. Omo-Gibe River Basin Integrated Development Master Plan Study, Final Report. Vols. I$\mathrm{XV}$.

World Bank. 2004. Ethiopia's Path to Survival and Development: Investing in Water Infrastructure. Background Note for FY04CEM. World_Bank_CP-WaterMila01.pdf.

World Bank. 2012a (Jul). AFCC2/RI-The Eastern Electricity Highway Project under the First Phase of the Eastern Africa Power Integration Program. http://www.worldbank.org/projects/P126579/regional-eastern-africa-power-pool-project-apl1?lang=en.

World Bank. 2012b (Jul). Fact Sheet: Ethiopia-Kenya Eastern Electricity Highway Project. First Phase of Regional Eastern Africa Power Integration Program. http://www.worldbank.org, http://search.worldbank.org/all?qterm=EEHP. 
World Bank. 2012c (June). Diagnosing Corruption in Ethiopia: Perceptions, Realities and the Way Forward for Key Sectors. (Janelle Plummer). http://dx.doi.org/10.1596/978-0-8213-9531-8.

World Bank. 2013 (Dec). Implementation Completion and Results Report on IDA Grants to the Federal Democratic Republic of Ethiopia for a Ethiopia Protection of Basic Services Program Phase II Project. Report No. ICR2574.

World Bank. 2014a (Mar.). Ethiopia - Promoting Basic Services Program Phase III Project: P128891 - Implementation Status Results Report. World Bank. 2014b (Nov 21). Ethiopia, Promoting Bassic Services Phase II Projet (P128891). Inspection Panel. Report No. 91854-ET.

Open Access This chapter is distributed under the terms of the Creative Commons Attribution-NonCommercial 2.5 International License (http:// creativecommons.org/licenses/by-nc/2.5/), which permits any noncommercial use, duplication, adaptation, distribution and reproduction in any medium or format, as long as you give appropriate credit to the original author(s) and the source, provide a link to the Creative Commons license and indicate if changes were made.

The images or other third party material in this chapter are included in the work's Creative Commons license, unless indicated otherwise in the credit line; if such material is not included in the work's Creative Commons license and the respective action is not permitted by statutory regulation, users will need to obtain permission from the license holder to duplicate, adapt or reproduce the material. 